\title{
Kekuatan Berlakunya Hukum Pidana Nasional Terhadap Warga Negara Indonesia yang Melakukan Tindak Pidana di Negara Lain
}

\author{
The Power of National Criminal Penal Code Against Indonesian Citizens Who \\ Conduct Criminal Acts in Other Countries
}

\author{
La Ode Muhamad Sulihin \\ Fakultas Hukum, Universitas Halu Oleo \\ E-mail: sulihinlaode@gmail.com; Imsulihin@uho.ac.id
}

\begin{abstract}
This paper examines about the power of national criminal penal code against Indonesian citizens who conduct criminal acts in other countries. This is done for the sake of the implementation of state responsibility to its citizens in providing legal protection for every citizen. In positive criminal law in Indonesia it adopts the territorial principle or the personal principle or the national principle is actively. In its application the territorial principle does not cause a legal problem, it is different when the personal principle or the national principle is actively applied strictly it will be contrary to the sovereignty of other countries where the crime is committed. Type of research used in this research was normative legal research or library legal research. The research approach used is statute approach and conceptual approach. The data used in this research is secondary data. How to collect data is done by means of library research. The data analysis method used in this study is a qualitative descriptive method. Based on the results of the study showed that the strength of the enactment of national criminal law against citizens who commit crimes in other countries is known as an active national principle. This active national principle implies the provision of a country's criminal law legislation to its citizens wherever they may be. However, in the context of Indonesia, the enactment of this active national principle is particularly relevant to criminal offenses-criminal acts called limitatively in the provisions of Article 5 of the Criminal Code. It is different when a citizen who commits a crime in another country but its existence has been in Indonesia, so in this case the provisions of Indonesian criminal law can be applied to its citizens.
\end{abstract}

Keyword: National Criminal Penal Code; Indonesian Citizens Who are Criminals; Other Countries

Abstrak: Tulisan ini mengkaji tentang kekuatan berlakunya hukum pidana nasional Indonesia terhadap warga negara Indonesia yang melakukan tindak pidana di 
negara lain. Hal ini dilakukan demi terlaksananya tanggung jawab negara terhadap warga negaranya dalam memberikan perlindungan hukum bagi setiap warga negaranya. Dalam hukum pidana positif di Indonesia mengadopsi asas teritorial maupun asas personal/prinsip nasional yang aktif. Dalam penerapannya asas teritorial tidak menimbulkan suatu problematik hukum, hal yang berbeda ketika asas personal atau prinsip nasional aktif diterapkan secara ketat maka akan bertentangan dengan kedaulatan negara lain dimana tindak pidana itu dilakukan. Tipe penelitian yang digunakan dalam penulisan ini adalah penelitian hukum normatif atau penelitian hukum kepustakaan. Pendekatan penelitian yang digunakan adalah pendekatan undang-undang dan pendekatan konseptual. Data yang digunakan dalam penelitian ini adalah data sekunder. Cara pengumpulan data dilakukan dengan cara penelitian kepustakaan. Metode analisis data yang digunakan dalam penelitian ini adalah metode deskriptif kualitatif. Berdasarkan hasil penelitian menunjukkan bahwa kekuatan berlakunya hukum pidana nasional terhadap Warga Negara Indonesia yang melakukan tindak pidana di negara lain dikenal dengan asas nasional aktif. Asas nasional aktif ini memberlakukan ketentuan peraturan perundang-undangan hukum pidana suatu negara terhadap warga negaranya di mana pun dia berada. Namun dalam konteks Indonesia pemberlakuan asas nasional aktif ini terkhusus kepada tindak pidana-tindak pidana yang disebut secara limitatif dalam ketentuan Pasal 5 KUHP. Hal yang berbeda ketika warga negara yang melakukan tindak pidana di negara lain tetapi keberadaannya telah berada di Indonesia, maka dalam hal ini ketentuan peraturan perundang-undangan hukum pidana Indonesia dapat diberlakukan terhadap warga negaranya.

Kata kunci: Hukum Pidana Nasional; Warga Negara Indonesia Pelaku Tindak Pidana; Negara Lain

\section{PENDAHULUAN}

Sejarah hukum pidana telah lama dikenal apa yang dikemukakan oleh Mayer yang disebut elementar prinsip atau oleh Van Hamel disebut grondbeginsel, yang kedua-duanya diterjemahkan dengan perkataan "asas dasar", yang menentukan bahwa "pada waktu mengadili seseorang yang dituduh telah melakukan suatu tindak pidana, hakim tidak dibenarkan memberlakukan undang-undang pidana lain kecuali yang berlaku di negaranya sendiri. ${ }^{1}$ Berlakukannya lex loci delicti (undang-undang yang berlaku di tempat tindak pidana itu telah dilakukan terhadap pelakunya), telah dikenal sejak abad ke-9. Sejak abad tersebut diberlakukannya undang-undang pidana suatu negara, baik terhadap warga negaranya sendiri maupun terhadap warga negara asing yang diketahui telah melakukan suatu tindak pidana di dalam wilayahnya. ${ }^{2}$

1 Van Hamel sebagaimana dikutip dalam P.A.F. Lamintang, Dasar-Dasar Hukum Pidana Indonesia, Jakarta Timur: Sinar Grafika, 2014, hlm. 85-86.

2 P.A.F. Lamintang, Dasar-Dasar Hukum Pidana Indonesia, Jakarta Timur: Sinar Grafika, 2014, Hlm. 85. 
Kaitannya dengan batas-batas berlakunya perundang-undangan hukum pidana suatu negara ditinjau dari sudut negara, ada dua kemungkinan pendirian, yaitu: pertama, perundang-undangan hukum pidana suatu negara berlaku bagi semua perbuatan pidana yang terjadi di dalam wilayah negara baik dilakukan oleh warga negaranya maupun oleh warga negara asing (asas teritorial). Kedua, perundang-undangan hukum pidana berlaku bagi semua perbuatan pidana yang dilakukan oleh warga negara, dimana saja, juga di luar wilayah negara (asas personal/prinsip nasional yang aktif). ${ }^{3}$ Asas pertama, titik berat diletakkan pada terjadinya perbuatan di dalam wilayah negara, siapa yang melakukannya tidak menjadi persoalan sedangkan pada asas kedua, titik berat diletakkan pada orang yang melakukan perbuatan pidana, tempat terjadinya perbuatan pidana tidak penting. ${ }^{4}$

Keberadaan dua asas ini dalam hukum pidana positif di Indonesia sama-sama diadopsi dalam KUHP. Kaitannya dengan asas teritorial tidak menimbulkan suatu problematik hukum, hal ini dikarenakan berlakunya asas ini didasarkan pada asas kedaulatan negara suatu bangsa, yang meliputi seluruh wilayah negara yang bersangkutan tanpa harus bertentangan dengan kedaulatan negara lain. Hal yang berbeda ketika asas personal atau prinsip nasional aktif diterapkan secara ketat maka akan bertentangan dengan kedaulatan negara lain dimana tindak pidana itu dilakukan. Hal ini dikarenakan titik tolak diadakannya asas nasional aktif ini adalah kewarganegaraan pelaku tindak pidana tanpa harus melihat tempat dimana tindak pidana itu dilakukan. ${ }^{5}$

Asas nasional aktif ini dilatarbelakangi oleh pemikiran bahwa undang-undang dari negara berdaulat senantiasa mengikuti warga negaranya. ${ }^{6}$ Adanya konsep kedaulatan negara yang mengajarkan bahwa setiap negara berdaulat juga dapat mengharapkan kepada setiap warga negaranya untuk tunduk patuh pada undang-undang negaranya di mana pun ia berada, dalam hal ini sekalipun tindak pidana itu dilakukan di negara lain.

Kaitannya dengan warga negara yang melakukan tindak pidana di negara lain, salah satu contoh yang belum lama ini terjadi adalah kasus pembunuhan Kim Jong-Nam yang salah satu pelakunya adalah warga negara Indonesia. Pembunuhan yang melibatkan salah satu WNI tersebut terjadi di bandara Malaysia. Saat itu, ia akan terbang menuju Makau dengan menaiki pesawat kelas ekonomi dari Kuala Lumpur International Airport 2 (KLIA2). Berikut adalah rekap dari dugaan pembunuhan Kim Jong-Nam berdasarkan

\footnotetext{
Moeljatno, Asas-Asas Hukum Pidana, Jakarta: Rineka Cipta, 2008, hlm. 42.

Ibid., hlm. 42-43.

A. Zainal Abidin Farid, Hukum Pidana I, Cetakan Kedua, Jakarta: Sinar Grafika, 2007, hlm. 155.

Mahrus Ali, Dasar-Dasar Hukum Pidans, Cetakan Kedua, Jakarta: Sinar Grafika, 2012, hlm. 88.
} 
keterangan kepolisian Malaysia, dikutip melalui Channel News Asia, Minggu 19 Februari 2017. Pada tanggal 13 Februari Kim Jong-Nam berjalan menuju ruang keberangkatan pukul 08.00 waktu setempat. Tiba-tiba, dua orang perempuan memukulnya. Keduanya disinyalir telah mengikuti Kim Jong-Nam. Salah satu wanita mengganggu Kim, sementara yang lain menyemprotkan cairan yang tidak diketahui jenisnya kepada Kim. Atau, satu wanita meraih wajahnya dari belakang dan menempelkan kain yang diyakini telah direndam cairan kimia sebelumnya. Kim meminta bantuan kepada pusat bantuan bandara. Ia memberitahu resepsionis merasa pusing. Menurut China Press, kata-kata terakhir Kim adalah: "Sangat menyakitkan, sangat menyakitkan, saya disemprot dengan cairan." Dia dibawa ke klinik yang berada satu lantai di bawah ruang kedatangan. Saat itu, ia mengalami kejang ringan dan diambang pingsan. Sesaat ambulans datang dan ia dikirim ke rumah sakit terdekat yaitu Rumah Sakit Putrajaya. "Dia meninggal dalam perjalanan menuju rumah sakit,"7

Kaitannya dengan kasus tersebut kalau merujuk kepada asas teritorial maka yang memiliki kewenangan untuk menerapkan peraturan perundang-undangnya hukum pidananya adalah negara Malaysia. Hal ini dikarenakan tempat terjadinya tindak pidana terjadi di negara Malaysia. Namun kalau merujuk kepada asas personalitas maka negara Indonesia pun berhak menerapkan peraturan perundang-undangannya terhadap warga negaranya sendiri. Apalagi dalam hukum pidana internasional ada prinsip umum hukum internasional dimana setiap negara berkewajiban melindungi warga negaranya dari penerapan hukum negara asing apalagi warga negara yang bersangkutan telah berada di negaranya sendiri. ${ }^{8}$ Prinsip hukum internasional ini merupakan perwujudan dari teori terbentuknya negara yang bersumber dari teori kontrak sosial. Teori kontrak sosial menjelaskan bahwa terbentuknya negara adalah karena anggota masyarakat mengadakan kontrak sosial untuk membentuk negara. Teori ini, sumber kewenangan adalah masyarakat itu sendiri negara memiliki tanggung jawab untuk melindungi setiap warga negara. Teori kontrak sosial tersebut dimaksudkan bahwa sudah semestinya negara Indonesia wajib melindungi warga negaranya.

Perlindungan hukum bagi setiap warga negara merupakan kewajiban yang harus dipenuhi oleh suatu negara. Begitu juga negara Indonesia yang wajib melindungi setiap

7 Anisa Widiarini, Kronologi Pembunuhan Kim Jong-nam, Viva.co.id, https://www.viva.co.id/berita/ nasional/884847-kronologi-pembunuhan-kim-jong-nam, diakses pada tanggal 5 Juni 2018.

8 Romli Atmasasmita, Kapita Selekta Hukum Pidana Internasional, Bandung: Utomo, 2004, hlm. 51. 
warga negaranya di mana pun dia berada. Hal ini sesuai dengan apa yang termaktub dalam Pembukaan Undang-Undang Dasar Negara Republik Indonesia Tahun 1945 alinea ke 4 (empat). ${ }^{9}$ Selanjutnya perlindungan tersebut merupakan salah satu hak warga negara yang diejawantahkan dalam Pasal 28D ayat (1) UUD 1945 yang menyatakan bahwa "Setiap orang berhak atas pengakuan, jaminan, perlindungan, dan kepastian hukum yang adil serta perlakuan yang sama di hadapan hukum". ${ }^{10}$ Dengan demikian dengan perlindungan hukum negara terhadap warga negara di satu sisi negara telah melaksanakan kewajibannya disisi lain hak dari warga negara yang diamanatkan oleh UUD 1945 dapat terpenuhi.

Berdasarkan beberapa uraian di atas, yang menjelaskan bahwa adanya tanggung jawab negara untuk memberikan perlindungan terhadap warga negaranya yang sala satunya adalah perlindungan hukum dari penerapan hukum negara asing, khawatirnya dalam sejarah penegakan hukum pidana apa yang terjadi dalam kasus James T. Riady terulang kembali terhadap warga negara Indonesia yang melakukan tindak pidana di negara lain. Kasus tersebut memunculkan banyak problematik hukum dari sisi tanggung jawab negara terhadap warga negaranya yaitu bagaimana seorang Warga Negara Indonesia yang didakwa telah melakukan suatu tindak pidana menurut hukum Amerika Serikat dapat begitu saja tunduk dan taat pada hukum Amerika Serikat tanpa ada bentuk perlindungan hukum dari negara terhadap warga negaranya dari penerapan hukum negara asing. Menyerahkan warga negara sendiri kepada negara lain untuk diadili dan dihukum oleh negara lain dianggap sebagai tindakan yang tidak melindungi warga negara.

Tidak dapat dipungkiri bahwa negara memiliki hubungan yang erat warga negaranya. Negara merupakan pelindung yang terbaik bagi warga negaranya dan memberikan jaminan akan adanya peradilan yang adil dan jujur. Maka apabila ada warga negara suatu negara yang setelah melakukan tindak pidana di negara lain dan kemudian kembali berlindung ke negaranya sendiri, maka warga negara tersebut hendaklah jangan diserahkan kepada negara yang mempunyai wewenang mengadili atas perkaranya. Tetapi, dalam rangka pemberantasan kejahatan di mana pun kejahatan itu terjadi dan supaya kejahatan yang telah dilakukan itu tidak berlalu demikian saja tanpa pemidanaan

\footnotetext{
9 Alinea ke- 4 UUD 1945 menyatakan bahwa tujuan negara ialah untuk melindungi segenap bangsa Indonesia dan seluruh tumpah darah Indonesia dan untuk memajukan kesejahteraan umum, mencerdaskan kehidupan bangsa, dan ikut melaksanakan ketertiban dunia yang berdasarkan kemerdekaan, perdamaian abadi dan keadilan sosial.

10 Lihat ketentuan Pasal 28 D ayat (1) UUD 1945.
} 
maka negara wajib dan harus sanggup mengadilinya. Untuk dapat melakukan ini negara tersebut harus dapat mampu memberlakukan hukumnya (pidana) terhadap kejahatan yang dilakukan warga negara lain. ${ }^{11}$ Berdasarkan uraian latar belakang di atas, maka patut dilakukan analisis kekuatan berlakunya hukum pidana nasional terhadap warga negara Indonesia yang melakukan tindak pidana di negara lain demi terlaksananya tanggung jawab negara terhadap warga negaranya.

\section{METODE PENELITIAN}

Secara khusus berdasarkan jenis, sifat, dan tujuannya suatu penelitian hukum dapat dibedakan menjadi dua yaitu penelitian hukum normatif, dan penelitian hukum empiris. ${ }^{12}$ Penelitian hukum normatif atau penelitian hukum kepustakaan adalah penelitian hukum yang dilakukan dengan cara meneliti bahan pustaka atau data sekunder belaka. Sedangkan penelitian hukum empiris atau sosiologis adalah penelitian hukum terutama meneliti data primer. $^{13}$ Tipe penelitian yang digunakan dalam penulisan ini adalah penelitian hukum normatif atau penelitian hukum kepustakaan.

Pendekatan penelitian yang digunakan adalah pendekatan undang-undang (statute approach) dan pendekatan konseptual (conseptual approach). Pendekatan undang-undang (statute approach) dilakukan dengan menelaah semua undang-undang dan regulasi yang bersangkut paut dengan isu hukum yang sedang ditangani. ${ }^{14}$ Sementara itu, pendekatan konseptual (conseptual approach) adalah pendekatan yang beranjak dari pandanganpandangan dan doktrin-doktrin yang berkembang dalam ilmu hukum. Tujuannya untuk menemukan ide-ide yang melahirkan pengertian-pengertian hukum, konsep-konsep hukum, dan asas-asas hukum yang relevan dengan isu hukum. ${ }^{15}$

Data yang akan digunakan dalam penelitian ini adalah data sekunder. Data sekunder merupakan jenis data yang diperoleh secara tidak langsung dari sumbernya, seperti bahan bacaan yang berupa buku, makalah atau hasil penelitian, dokumen, peraturan perundangan, putusan pengadilan, data statistik dan lain sebagainya.

Cara pengumpulan data dilakukan dengan cara penelitian kepustakaan. Penelitian

11 M. Budiarto, Ekstradisi dalam Hukum Nasional, Jakarta: Ghalia Indonesia, 1981, hlm. 70.

12 Bambang Waluyo, Penelitian Hukum Dalam Praktek, Cetakan Pertama, Jakarta: Sinar Grafika, 1991, hlm. 13.

13 Soerjono Soekanto dan Sri Mamudji, Penelitian Hukum Normatif: Suatu Tinjauan Singkat, Edisi 1,-12. Jakarta: PT. Raja Grafindo Persada, 2010, hlm. 13-14.

14 Peter Mahmud Marzuki, Penelitian Hukum, Jakarta: Kencana Prenada Group, 2005, hlm. 93.

15 Ibid. hlm. 95 
kepustakaan yaitu untuk memperoleh data sekunder, yaitu mengkaji bahan hukum, baik bahan hukum primer, bahan hukum sekunder maupun bahan hukum tersier yang berkaitan dengan permasalahan yang akan dikaji dan diteliti guna memperkuat analisis data sekunder. Metode analisis data yang digunakan dalam penelitian ini adalah metode deskriptif kualitatif yaitu mencari dan mengumpulkan data yang ada hubungannya dengan objek dan permasalahan yang akan diteliti yang kemudian diambil dan disusun secara sistematis untuk mendapatkan gambaran yang jelas dan lengkap.

\section{ANALISIS DAN PEMBAHASAN}

Sebelum mengulas mengenai kekuatan berlakunya hukum pidana nasional terhadap warga negara yang melakukan tindak pidana di negara lain, terlebih dahulu akan diulas prinsip-prinsip atau asas-asas berlakunya perundang-undangan hukum pidana menurut tempat terjadinya perbuatan. Kaitannya dengan hal itu, hampir semua negara dalam perundang-undangan hukum pidananya menerapkan asas teritorial. Oleh Moeljatno asas teritorial ini diartikan bahwa perundang-undangan hukum pidana suatu negara berlaku bagi semua orang yang melakukan perbuatan pidana di negara tersebut, baik oleh warga negara sendiri maupun warga negara asing. ${ }^{16}$ Selain asas teritorial ini, dalam rangka mengantisipasi berbagai kejahatan yang dilakukan di luar wilayah suatu negara, hukum pidana mengenal adanya perluasan yurisdiksi teritorial. Perluasan teritorial tersebut meliputi perluasan teknis, perluasan berdasarkan kewarganegaraan, perluasan berdasarkan proteksi, dan perluasan berdasarkan prinsip universal. ${ }^{17}$

Selanjutnya penulis akan menguraikan secara singkat berbagai perluasan yurisdiksi teritorial yang akan mempengaruhi kekuatan berlakunya peraturan perundangundangan hukum pidana suatu negara, sebagai berikut: 18

1. Perluasan berdasarkan prinsip teknis

a. Wilayah laut Indonesia sebelum tahun 1957, menurut "territorial zee en maritieme kringen ordinatie" (Stb 1939 No. 442) adalah 3 mil laut yang dihitung dari batas garis pasang surut sesuai dengan hukum kebiasaan internasional

16 Moeljatno, Asas-Asas Hukum Pidana, Jakarta: Rineka Cipta, 2008, hlm. 42.

17 Eddy O.S Hiariej, Pengantar Hukum Pidana Internasional, Jakarta: Erlangga, 2009, hlm. 37.

18 Eddy O.S Hiariej, Hukum Pidana, Cetakan Keenam, Universitas Tangerang Selatan: Terbuka, 2017, hlm. 5.23 . 
b. Pada saat berjalannya Kabinet Karya di bawah Perdana Menteri Juanda pada tanggal 13 Desember 1957, dikeluarkan pengumuman yang intinya "menyatakan bahwa batas teritorial Indonesia lebarnya 12 mil yang diukur dari garis-garis yang menghubungkan titik yang terluar pada pulau negara Republik Indonesia akan ditentukan dengan undang-undang.

c. Ketentuan pasal 2 diperluas oleh pasal 3 termasuk melakukan tindak pidana dalam kendaraan air Indonesia dan pesawat udara Indonesia”.

2. Perluasan Teritorial Berdasarkan Prinsip Kewarganegaraan

a. Asas nasional aktif

Asas nasional aktif bertumpu pada kewarganegaraan pembuat hukum pidana mengikuti kewarganegaraannya ke mana pun ia berada. Inti asas ini tercantum di dalam Pasal 5 KUHP

b. Asas nasional pasif

Asas nasional pasif adalah asas yang menyatakan berlakunya undangundang hukum pidana Indonesia di luar wilayah negara bagi setiap orang, warga negara atau orang asing yang melanggar kepentingan hukum Indonesia, atau melakukan perbuatan pidana yang membahayakan kepentingan nasional di luar negeri.

3. Perluasan teritorial berdasarkan prinsip universal

a. Asas universal adalah asas yang menyatakan setiap orang yang melakukan perbuatan pidana dapat dituntut undang-undang hukum pidana Indonesia di luar wilayah negara untuk kepentingan hukum bagi seluruh dunia.

b. Melindungi kepentingan internasional (kepentingan universal) karena rumusan pasal 4 ke-2 KUHP (mengenai kejahatan pemalsuan mata uang atau uang kertas) dan Pasal 4 ke-4 KUHP (mengenai pembajakan kapal laut dan pembajakan pesawat udara) tidak menyebutkan mata uang atau uang kertas negara yang dipalsukan atau kapal laut atau pesawat terbang negara yang dibajak.

Berdasarkan beberapa perluasan tersebut, kaitannya dengan kekuatan berlakunya hukum pidana suatu negara sebagaimana diulas sebelumnya secara garis besar ada 2 kemungkinan pendirian yaitu: 
1. Perundang-undangan hukum pidana suatu negara berlaku bagi semua perbuatan pidana yang terjadi di dalam wilayah negara baik dilakukan oleh warga negaranya maupun oleh warga negara asing (asas teritorial).

2. Perundang-undangan hukum pidana berlaku bagi semua perbuatan pidana yang dilakukan oleh warga negara, di mana saja, juga di luar wilayah negara (asas personal/prinsip nasional yang aktif). ${ }^{19}$

Dari dua asas kekuatan berlakunya hukum pidana suatu negara, asas pertamalah yang lazim dipakai oleh kebanyakan negara, termasuk Indonesia. Lain halnya dengan asas yang kedua (asa personal) tidak mungkin lagi digunakan sepenuhnya di dalam wilayah negara lain yang kedudukannya sama-sama berdaulat. Tetapi, asas personal atau asas nasional aktif ini dapat berlaku khusus terhadap tindak pidana tertentu, sebagaimana yang diamanatkan dalam Pasal 5 KUHP, sebagai berikut:

(1) Aturan pidana dalam perundang-undangan Indonesia berlaku bagi warga negara yang di luar Indonesia melakukan

Ke-1: salah satu kejahatan tersebut dalam Bab I dan II Buku Kedua dan pasalpasal 160, 161, 240, 279, 450, dan 451 .

Ke-2: salah satu perbuatan yang oleh suatu ketentuan pidana dalam perundang-undangan Indonesia dipandang sebagai kejahatan, sedangkan menurut perundang-undangan negara dimana perbuatan dilakukan diancam dengan pidana.

(2) Penuntutan perkara sebagai mana dimaksud dalam sub kedua dapat dilakukan juga jika terdakwa menjadi warga negara sesudah melakukan perbuatan.

Berdasarkan ketentuan Pasal 5 KUHP, asas nasional aktif tidak berlaku untuk semua tindak pidana tetapi khusus untuk tindak pidana-tindak tertentu saja sebagaimana disebutkan dalam ketentuan aquo. Adapun golongan tindak pidana yang dapat diberlakukan asa nasional aktif adalah sebagai berikut: 20

1. Dari bab I dan Bab 2 Buku II KUHP yang meliputi kejahatan-kejahatan terhadap keamanan negara seperti pemberontakan, makelar, usaha membunuh kepala negara, dan terhadap kedudukan kepala negara (misdrijven tegen de

19 Moeljatno, Op. cit, hlm. 42.

20 Wirjono Prodjodikoro, Asas-Asas Hukum Pidana Di Indonesia, Cetakan Enam, Bandung: Refika Aditama, 2014, hlm. 54. 
waardigheid van den president), seperti menghina kepala negara, menyerang kepala negara secara fisik.

2. Pasal 160 dan 161 KUHP yang berupa penghasutan (opruiing) untuk melakukan tindak pidana.

3. Pasal 240 KUHP yang berupa tidak memenuhi kewajiban dalam bidang pertahanan negara.

4. Pasal 279 KUHP yang berupa tidak memenuhi kewajiban melebihi jumlah yang diperbolehkan.

5. Pasal 450 dan 451 yang berupa turut serta, tanpa izin Pemerintah Indonesia, dalam kapal dinas negara asing yang melakukan pengambilan kapal-kapal lain.

Ketentuan tersebut di atas mengisyaratkan bahwa aturan hukum pidana Indonesia pada dasarnya dapat diberlakukan terhadap warga negara Indonesia yang melakukan tindak pidana sekalipun tindak pidana itu dilakukan di luar wilayah Indonesia, tetapi dengan syarat; (1) perbuatan yang dilakukan oleh warga negara Indonesia itu harus merupakan tindak pidana menurut hukum Indonesia dan substansi perbuatan itu juga cenderung mengarah kepada ancaman terhadap kepentingan nasional Indonesia; dan (2) perbuatan yang dilakukannya itu juga harus merupakan tindak pidana menurut hukum di negara di mana perbuatan itu dilakukan oleh warga negara Indonesia. ${ }^{21}$

Pendapat Moeljatno terhadap ketentuan pasal 5 KUHP mengandung dua makna. Pertama, pemberlakuan aturan hukum pidana Indonesia terhadap warga negara Indonesia yang melakukan tindak pidana di luar Indonesia hanyalah berkaitan dengan pasal-pasal tertentu saja, yang substansinya melindungi kepentingan nasional. Pasal 5 KUHP sesungguhnya memiliki substansi yang sama dengan Pasal 4 KUHP, hanya saja kepentingan-kepentingan yang hendak diperluas sampai pada keamanan negara dan keagungan kepala negara, penghasutan terhadap kekuasaan negara dan sebagainya (Pasal 160-161), membikin dirinya tidak mampu untuk menjalani wajib tentara (Pasal 279), merampok untuk kepentingan suatu negara terhadap kapal-kapal dari negara musuh. Kedua, diadakannya Pasal 5 ke-2 KUHP bertujuan untuk mencegah agar warga negara Indonesia di luar Indonesia tidak melakukan tindak pidana. jika ketentuan tersebut tidak ada, maka warga negara Indonesia yang melakukan tindak pidana di luar Indonesia bisa menghindar dari penuntutan pidana di negara tersebut. Jika negara yang bersangkutan

21 Mahrus Ali, Op. cit., hlm. 89. 
meminta warga negara Indonesia tadi untuk diadili di negara tersebut, hal demikian tidak mungkin karena pada prinsipnya warga negara sendiri tidak dapat diserahkan kepada negara asing untuk diadili di negara tersebut. ${ }^{22}$

Hal yang berbeda dengan kekuatan berlakunya hukum pidana suatu negara terhadap warga negaranya yang melakukan tindak pidana di negara lain tetapi keberadaan warga negara tersebut sekarang berada di negara asalnya. Terhadap hal tersebut maka muncul suatu problem hukum di satu sisi negara tempat dia melakukan tindak pidana berhak untuk melakukan segala proses hukum berdasarkan prinsip teritorial namun disisi ada prinsip hukum pidana internasional, dimana setiap negara berkewajiban melindungi warga negaranya dari penerapan hukum negara asing walaupun warga negara Indonesia tersebut melakukan tindak pidana di negara asing. Selain itu dalam hal negara tempat terjadinya tindak pidana ingin melakukan segala proses hukum terhadap seseorang yang telah berada negaranya sendiri maka jalur yang harus ditempuh adalah jalur ekstradisi.

Ekstradisi di sini menurut Remmelink sebagai penyerahan seorang tersangka atau terdakwa atau terpidana oleh negara tempat dimana orang tersebut berada kepada negara lain yang hendak mengadili orang yang diminta atau melaksanakan putusan pengadilan negara dari negara yang diminta. ${ }^{23}$ Berdasarkan ketentuan Undang-Undang Nomor 1 Tahun 1979 tentang Ekstradisi, pengertian ekstradisi dirumuskan sebagai berikut, "Penyerahan oleh suatu negara kepada negara yang meminta penyerahan seseorang yang disangka atau dipidana karena melakukan sesuatu kejahatan di luar wilayah negara yang menyerahkan dan di dalam yurisdiksi wilayah negara yang meminta penyerahan tersebut, karena berwenang untuk mengadili dan memidananya." Perumusan tersebut dimuat dalam Bab 1 Ketentuan Umum Pasal 1.24 Namun dalam hal penyerahan seorang tersangka atau terdakwa atau terpidana oleh negara tempat di mana orang tersebut berada kepada negara lain yang hendak mengadili, ada asas yang kemudian berlaku yaitu asas tidak menyerahkan warga negaranya sendiri. Artinya, jika tersangka, terdakwa atau terpidana yang diminta adalah warga negara dari negara yang diminta, maka negara yang diminta berhak untuk tidak menyerahkan warga negaranya kepada negara yang meminta. Hal ini

22 Moeljatno, Op. cit., hlm. 42.

23 Remmelink sebagaimana dikutip oleh Eddy O.S Hiariej, Pengantar Hukum Pidana Internasional, Jakarta: Erlangga, 2009, hlm. 40.

24 M. Budiarto, Ekstradisi Dalam Hukum Nasional, Jakarta: Ghalia Indonesia, 1981, hlm. 7. 
berkaitan dengan apa yang disebut dengan martabat bangsa atau dalam hukum Prancis dikenal dengan istilah dignite nationale. ${ }^{25}$

Pengaturan mengenai asas bahwa negara yang diminta mempunyai hak untuk tidak menyerahkan warga negaranya sendiri diatur dalam Pasal 7 ayat (1) Undang-Undang Nomor 1 Tahun 1979 tentang Ekstradisi, sebagai berikut:26 "Permintaan ekstradisi terhadap warga negara Republik Indonesia ditolak" Dicantumkannya pasal 7 ayat (1) Undang-Undang Nomor 1 Tahun 1979 pada dasarnya memberikan kekuasaan kepada negara-negara untuk tidak menyerahkan warga negaranya sendiri yang dituduh melakukan kejahatan di dalam wilayah negara lain atau di luar wilayah suatu negara. Oleh karena itu, jika orang yang diminta ternyata adalah warga negara dari negara diminta, negara tersebut mempunyai kekuasaan untuk menolak permintaan negara peminta. Dicantumkannya pasal ini di dalam perjanjian dan perundang-undangan ekstradisi, disebabkan oleh karena kewarganegaraan seseorang sangat memegang peranan penting yaitu menyangkut status dari orang yang bersangkutan, dan dengan demikian hukum yang berlaku atas dirinya terutama yang menyangkut status personalnya tergantung dari kewarganegaraan orang tersebut. Hal ini adalah logis dan masuk akal, sebab seperti yang dikatakan oleh J.G. Starke dimana kewarganegaraan itu tiada lain dari pada keanggotaan seseorang pada suatu negara. ${ }^{27}$ Walaupun demikian ada kemungkinan warga negara sendiri yang melakukan kejahatan di negara lain dapat diadili dengan hukum negara tempat dimana dia melakukan kejahatan (di negara peminta). Namun, hal tersebut dapat dilakukan dengan mengingat pertimbangan-pertimbangan demi kepentingan negara, hukum dan keadilan, seperti yang dirumuskan dalam Pasal 7 ayat (2) Undang-Undang Nomor 1 Tahun 1979 tentang Ekstradisi, sebagai berikut:28 "penyimpangan terhadap ketentuan ayat (1) tersebut di atas dapat dilakukan apabila orang yang bersangkutan karena keadaan lebih baik diadili di tempat dilakukannya kejahatan".

Selain pertimbangan di atas, menurut penulis kaitannya dengan perlindungan terhadap warga negara sendiri, maka yang dapat menjadi pertimbangan misalnya jika dia diserahkan akan dikhawatirkan dia akan diadili menurut sistem hukum dan peradilan yang sangat lain dan asing jika dibandingkan dengan sistem dan peradilan di negaranya

25 Eddy O.S Hiariej, Pengantar Hukum Pidana Internasional, Jakarta: Erlangga, 2009, hlm. 41-42.

26 Pasal 7 ayat (1) Undang-Undang Nomor 1 Tahun 1979 tentang Ekstradisi.

27 I Wayan Parthiana, Ekstradisi Dalam Hukum Internasional dan Hukum Nasional, Bandung: Alumni, 1983, hlm. 62.

28 Pasal 7 ayat (2) Undang-Undang Nomor 1 Tahun 1979 tentang Ekstradisi. 
sendiri dan dikhawatirkan peradilan yang dilakukan oleh negara peminta tidak berjalan secara jujur, bebas dan obyektif sehingga warga negaranya yang diadili itu betul-betul tidak memperoleh keadilan yang sama seperti kalau dia diadili dan dihukum di negaranya sendiri.

Sebenarnya, kaitannya dengan tidak menyerahkan warga negara sendiri (non ex tradition of nationals) itu bisa merupakan suatu larangan mutlak (absolute prohibition) artinya, negara diminta berdasarkan pertimbangan apa pun juga tidak boleh menyerahkan warga negaranya sendiri, ataukah hanya sebagai suatu kebijaksanaan (discretion) artinya, negara yang diminta berdasarkan alasan-alasan dan pertimbangan tertentu dapat mengambil kebijaksanaan untuk menyerahkan atau menolak menyerahkan warga negaranya. Apabila ketentuan yang mengatur tentang penyerahan warga negara itu berbunyi extradition shall not be granted if the person who is requested by the requesting state is the nationals of the requested state atau A contracting stete shall not surrender its own nationals, ketentuan yang rumusannya seperti ini tegas-tegas melarang secara mutlak negara yang diminta untuk menyerahkan warga negaranya sendiri. Jadi, bagaimanapun juga negara yang diminta harus menolak permintaan negara peminta apabila orang yang diminta atau pelaku kejahatan itu adalah warga negaranya sendiri. Tetapi jika ketentuannya berbunyi the contracting parties shall be under no obligation to surreder their own nationals atau each party shall have the right to refuse extradition of its nationals. Ketentuan semacam ini memberikan kebijaksanaan (discretion) kepada negara yang diminta untuk mengambil keputusan apakah akan menyerahkan atau menolak untuk menyerahkan warga negaranya. Artinya bahwa pihak yang mempunyai hak untuk menyerahkan dapat memutuskan apakah akan menggunakan haknya ataukah tidak, atau dengan kata lain negara diminta dapat mengambil kebijaksanaan apakah akan menyerahkan warga negaranya ataukah tidak. ${ }^{29}$

Berdasarkan ketentuan-ketentuan dan pertimbangan-pertimbangan hukum di atas, maka kekuatan berlakunya hukum pidana Indonesia dapat berlaku terhadap warga negara yang melakukan tindak pidana di negara lain yang keberadaannya sekarang berada di negara Indonesia. Tidak dapat dipungkiri bahwa adanya hubungan yang erat antara negara dengan warganegaranya dan bahwa negara sendiri merupakan pelindung yang terbaik bagi warganegaranya dan yang akan memberikan jaminan akan adanya peradilan

29 I Wayan Parthiana, Op. cit., hlm. 116-117. 
yang adil dan jujur. Maka apabila ada warga negara suatu negara yang setelah melakukan kejahatan di negara asing dan kemudian kembali berlindung ke negaranya sendiri, maka warga negara tersebut hendaklah jangan diserahkan kepada negara yang mempunyai wewenang mengadili atas perkaranya. Tetapi, dalam rangka pemberantasan kejahatan di mana pun kejahatan itu terjadi dan supaya kejahatan yang telah dilakukan itu tidak berlalu demikian saja tanpa pemidanaan, apabila negara yang bersangkutan tidak menyerahkan warga negaranya sendiri, negara itu wajib dan harus sanggup mengadilinya. Untuk dapat melakukan ini negara tersebut harus dapat mampu memberlakukan hukumnya (pidana) terhadap kejahatan yang dilakukan warga negaranya di luar negeri. ${ }^{30}$

Dalam hal negara yang diminta menolak untuk menyerahkan warga negaranya, negara peminta dapat meminta kepada negara yang diminta itu supaya mengadili sendiri warga negaranya serta negara yang diminta berkewajiban untuk mengadili dengan menyerahkan kepada badan peradilannya yang berwenang. Seperti dalam kasus Bob Liem, antara Indonesia dan Hong Kong dimana Bob Liem yang berkewarganegaraan Indonesia ketika berada di Hong Kong, telah membunuh istrinya dan seorang anak perempuannya sendiri, kemudian dia bersembunyi di Indonesia. Bob Liem ditangkap oleh polisi Indonesia, dan kemudian diajukan ke hadapan pengadilan Negeri Jakarta Raya. Sebelum diajukan ke pengadilan, pemerintah Hong Kong telah mengajukan permintaan penyerahan kepada Indonesia atas diri Bob Liem, karena kejahatan itu dilakukan di Hong Kong sebagai locus delicti. Akan tetapi Indonesia menolak permintaan penyerahan ke Hong Kong, bukan karena antara Indonesia dan Hong Kong belum terikat oleh perjanjian ekstradisi, melainkan karena Bob Liem berkewarganegaraan Indonesia. ${ }^{31}$

Menyerahkan warga negara sendiri kepada negara lain dianggap sebagai tindakan yang tidak melindungi warga negara. Apalagi menyerahkan warga negara untuk diadili dan dihukum oleh negara lain, lebih-lebih jika sistem hukum kaumnya berbeda yang akibatnya sangat merugikan orang yang bersangkutan baik lahir maupun batin, ibarat tumbuh-tumbuhan atau hewan yang dipindahkan ke daerah yang iklim dan tingkat kesuburannya berbeda. Setiap orang dianggap lebih cocok dengan sistem hukum yang berlaku di negaranya sendiri dari pada sistem hukum negara lain. Oleh karena itu akan lebih baik jika dia diadili di negaranya sendiri. Selain itu, kalau ditinjau dari segi sosiologis dan psikologis, memang ada baiknya jika orang yang diminta atau pelaku kejahatan itu

30 M. Budiarto, Op. cit., hlm. 70.

31 Ibid., hlm. 118. 
diadili serta menjalani hukuman di dalam wilayah negaranya sendiri, berada dalam penjara atau lembaga pemasyarakatan dia dapat bergaul dengan para narapidana sebangsa dan setanah airnya yang memiliki latar belakang kebudayaan dan falsafah hidup yang sama, dibandingkan jika dia diadili dan menjalani hukuman diwilayah negara lain. ${ }^{32}$

\section{KESIMPULAN}

Kekuatan berlakunya hukum pidana nasional terhadap Warga Negara Indonesia yang melakukan tindak pidana di negara lain dikenal dengan asas nasional aktif. Asas nasional aktif ini memberlakukan ketentuan peraturan perundang-undangan hukum pidana suatu negara terhadap warga negaranya di mana pun dia berada. Namun dalam konteks Indonesia pemberlakuan asas nasional aktif ini terkhusus kepada tindak pidana-tindak pidana yang disebut secara limitatif dalam ketentuan Pasal 5 KUHP. Hal yang berbeda ketika warga negara yang melakukan tindak pidana di negara lain tetapi keberadaannya telah berada di Indonesia, maka dalam hal ini ketentuan peraturan perundang-undangan hukum pidana Indonesia dapat diberlakukan terhadap warga negaranya. Artinya bahwa asas nasional aktif tidak hanya terbatas terhadap ketentuan yang ada dalam Pasal 5 KUHP tetapi berlaku juga terhadap Warga Negara yang melakukan tindak pidana di negara lain yang keberadaannya telah kembali di negara asalnya.

\section{Daftar Pustaka}

\section{Buku}

Ali, Mahrus, Dasar-Dasar Hukum Pidans; Cetakan Kedua, Jakarta: Sinar Grafika, 2012. Atmasasmita, Romli, Kapita Selekta Hukum Pidana Internasional, Bandung: Utomo, 2004. Farid, A. Zainal Abidin, Hukum Pidana I, Cetakan Kedua, Jakarta: Sinar Grafika, 2007. Hiariej, Eddy O.S, Hukum Pidana, Cetakan Keenam, Tangerang Selatan: Universitas Terbuka, 2017.

Hiariej, Eddy O.S, Pengantar Hukum Pidana Internasional, Jakarta: Erlangga, 2009. Lamintang, P.A.F., Dasar-Dasar Hukum Pidana Indonesia, Jakarta Timur: Sinar Grafika, 2014.

M. Budiarto, Ekstradisi Dalam Hukum Nasional, Jakarta: Ghalia Indonesia, 1981.

Marzuki, Peter Mahmud, Penelitian Hukum, Jakarta: Kencana Prenada Group, 2005.

32 Ibid., hlm. 120. 
Moeljatno, Asas-Asas Hukum Pidana, Jakarta: Rineka Cipta, 2008.

Moeljatno, Kitab Undang-Undang Hukum Pidana, Jakarta: Bumi Aksara, 2012.

Parthiana, I. Wayan, Ekstradisi Dalam Hukum Internasional dan Hukum Nasional, Bandung: Alumni, 1983.

Prodjodikoro, Wirjono, Asas-Asas Hukum Pidana di Indonesia, Cetakan Enam, Bandung: Refika Aditama, 2014.

Soekanto, Soerjono dan Sri Mamudji, Penelitian Hukum Normatif: Suatu Tinjauan Singkat, Edisi 1,-12. Jakarta: PT. Raja Grafindo Persada, 2010.

Waluyo, Bambang, Penelitian Hukum Dalam Praktek, Cetakan pertama, Jakarta: Sinar Grafika, 1991.

\section{Peraturan Perundang-undangan}

Undang-Undang Dasar Negara Republik Indonesia Tahun 1945

Undang-Undang Nomor 1 Tahun 1979 tentang Ekstradisi (Lembaran Negara Republik Indonesia Tahun 1979 Nomor 2, Tambahan Lembaran Negara Republik Indonesia Nomor 3130)

\section{Situs Web}

Widiarini, Anisa, Kronologi Pembunuhan Kim Jong-nam, Viva.co.id, https://www.viva.co.id/berita/nasional/884847-kronologi-pembunuhan-kimjong-nam, diakses pada tanggal 5 Juni 2018. 